\title{
Statyba
}

\section{WEATHER DURABILITY OF EXTERNAL WALL THERMAL INSULATION SYSTEM WITH A THIN- LAYER PLASTER FINISH}

\section{J. Ramanauskas \& V. Stankevičius}

To cite this article: J. Ramanauskas \& V. Stankevičius (1998) WEATHER DURABILITY OF EXTERNAL WALL THERMAL INSULATION SYSTEM WITH A THIN-LAYER PLASTER FINISH, Statyba, 4:3, 206-213, DOI: 10.1080/13921525.1998.10531406

To link to this article: https://doi.org/10.1080/13921525.1998.10531406

曲 Published online: 26 Jul 2012.

Submit your article to this journal $₫$

ЏII Article views: 151 


\title{
WEATHER DURABILITY OF EXTERNAL WALL THERMAL INSULATION SYSTEM WITH A THIN-LAYER PLASTER FINISH
}

\author{
J. Ramanauskas, V. Stankevičius
}

\section{Introduction}

Additionally insulated walls in Lithuania is a relatively new kind of construction. Higher requirements for the thermal resistance of the walls of the buildings came into force in Lithuania only some years ago. Economical profit started to be taken into consideration not long ago after a sudden growth of thermal energy prices.

One of the solutions widely used abroad is the fastening of hard mineral wool or polystyrene foam boards on external side of walls with finish by thinlayer plaster (Fig 1). Usually such structures are considered as heat insulating systems $[1,2]$.

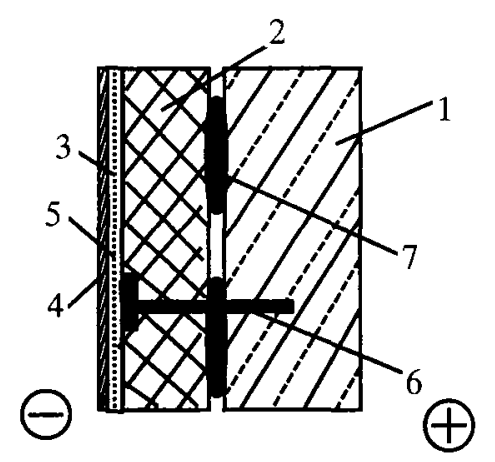

Fig 1. Principal scheme of the walls with external insulation protected and finished with thin-layer plaster: 1 - bearing wall layer; 2 - thermal insulating material; 3 - reinforcing plaster layer; 4 - plaster finish layer; 5 - glass fiber fixing net; 6 - fixing detail made of glass fibber; 7 - glue

Usually the wall insulation in buildings is installed with the view of economical profit, in parallel with hygienic and indoor climate improvement. The main economical criterion is the pay-back period of investment consumed for the wall insulation. The requirement from this statement would be as follows: the lifetime of an insulating system should be longer than its economical pay-back period.
In regard to recent economical situation in Lithuania, the economical pay-back period of wall insulation, especially in cases of additional insulation of existing buildings, can exceed twenty years. This is a long time, and requirements concerning the weather durability of insulating system become extremely important. It seems to be profitable to use only materials of very good quality, durable and relatively cheap.

A trustworthy method with scientific background for quality control and forecast of weather durability is needed to ensure the use of reliable and durable materials in construction.

\section{Selection of the investigation method for estimation of weather durability}

The materials of finish layer are mostly deteriorated by climatic changes.

A principal research scheme for evaluation of durability for materials and construction due to climatic effects, according to which the methods of modelling required at the estimation of resistance for climate effects should be selected, has been elaborated and is presented in Fig 2. The method ought to be selected in regard to climatic effects acting on examined materials in reality and with regard to the possibility to simulate them in laboratory. The usability of the selected method is checked by analysis of the results which have been obtained according to the method applied, physical- mechanical properties of materials with regard to the general laws of material deterioration, and the experience in investigations of weather durability forecast. The accuracy of selected method of weather durability forecast could be finally evaluated only by a sufficient amount of field investigation results. This means, that the systems under consideration should reach the age of deterioration under natural field conditions. 


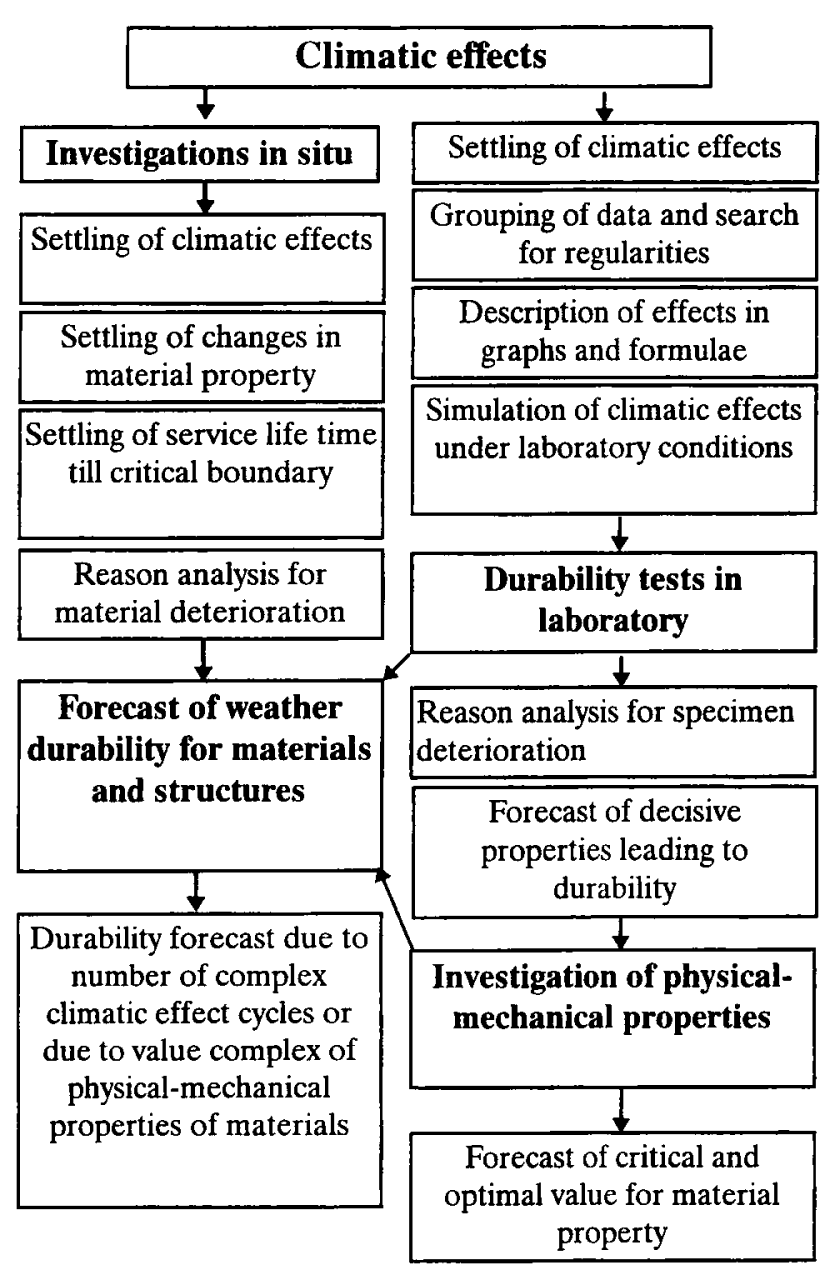

Fig 2. The principal resistance examination scheme for materials and structures due to climatic effects

In the laboratory of building thermal physics at the Institute of Architecture and Construction a testing method of weather durability has been developed. A wide range of building materials (ceramic finish masonry, concrete with expanded clay filling, cellular concrete, various finish materials) have been tested according to it [3]. Investigations of the ceramic brick masonry have been carried out especially - the relation between the weather durability in a climatic chamber and real service life in years, with regard to the terms of service and building location region has been established and confirmed by field observations [4]. The method has been approved by field observation data. The method under consideration with some improvements made has been applied for investigation of weather durability of thermal insulating systems with thin-layer finish.

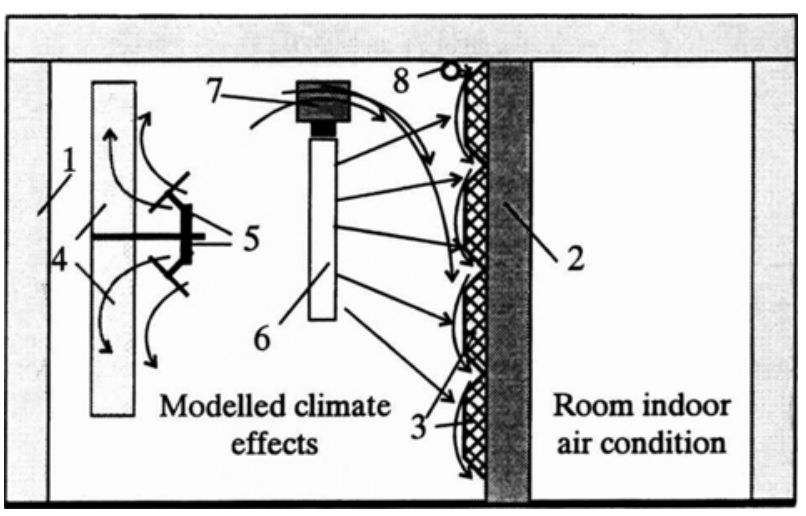

Fig 3. Climatic chamber scheme: 1 - chamber insulation; 2 - wall; 3 - samples; 4 - freezing equipment; 5-ventilators; 6 - heater; 7 - ventilator; 8 - water-sprinkling system

The thermal insulating systems were tested in a climatic chamber divided into two sections by masonry partition. The equipment of climatic effects was installed at one side of the partition, at the other - the equipment for maintenance of the indoor air condition (Fig 3).

The effects of aggressive thaw-freezing periods with rains which often occur during winter in Lithuania are simulated in the climatic chamber by modelled cycles of raining-freezing-heating.

The main actions in the climatic chamber at the performance of modelled raining-freezing-heating cycles are as follows:

- during raining, the water under pressure from supply tube (8) is spread out on the top of the wall under test. The water is falling down covering the surface by continuous water film. The surface temperature of the wall is dropped down to $10 \pm 2{ }^{\circ} \mathrm{C}$;

- during freezing, the air temperature in section of climatic effects of the chamber is decreased to -15 ${ }^{\circ} \mathrm{C}$ by refrigerating equipment (4). Fans (5) are blowing air on heat exchanger of refrigerator. By these means the effectiveness of refrigerator is increased (the heat transfer coefficient is increased). Fan (7) is used for air mixing in the space of this section and the temperature decrease at the surface of specimens then is more uniform and quicker;

- at the end of freezing, the refrigerators are turned off and heating device (6) is turned on; temperature in space is increased to the provided limit $\left(+25^{\circ} \mathrm{C}\right)$ 


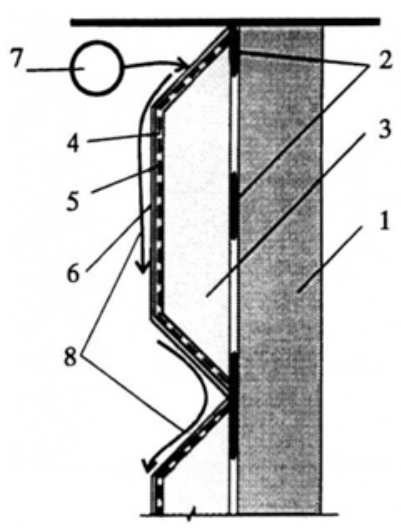

Fig 4. The structural fragment of chamber tests: 1 - bearing wall layer; 2 - glue for fixing of heat insulation to the wall; 3 - heat insulation; 4 - reinforcing plaster layer; 5 - glass fiber fixing net; 6 - finish plaster layer; 7 - water sprinkling tube; 8 - water layer

- during heating, fan (7) is mixing air in space of section too; then the temperature is increased more rapidly and the specimen surface is drying better;

- at the end of heating, the heating device and fan are turned off and raining is continued.

Mounting scheme of specimens under testing in the climatic chamber is presented in Fig 4.

The time-schedule of raining-freezing-heating cycle:

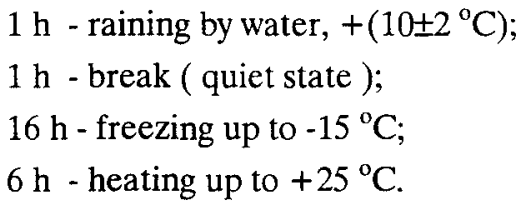

\section{Estimation of data received by a selected investiga- tion method}

During testing by the selected method, in the beginning the attention was paid to the different character of specimen deterioration. Finish as structural aggregate is falling into deterioration according to the schemes, presented in Fig 5. Structural deterioration is deepened and accelerated by developing later local ageing and deterioration processes of materials themselves.

The schemes of finish deterioration in Fig 5 could be explained as follows:

a) the cracks occur on external surface, they become thicker, growing into a net, the finish layer begins to destroy;
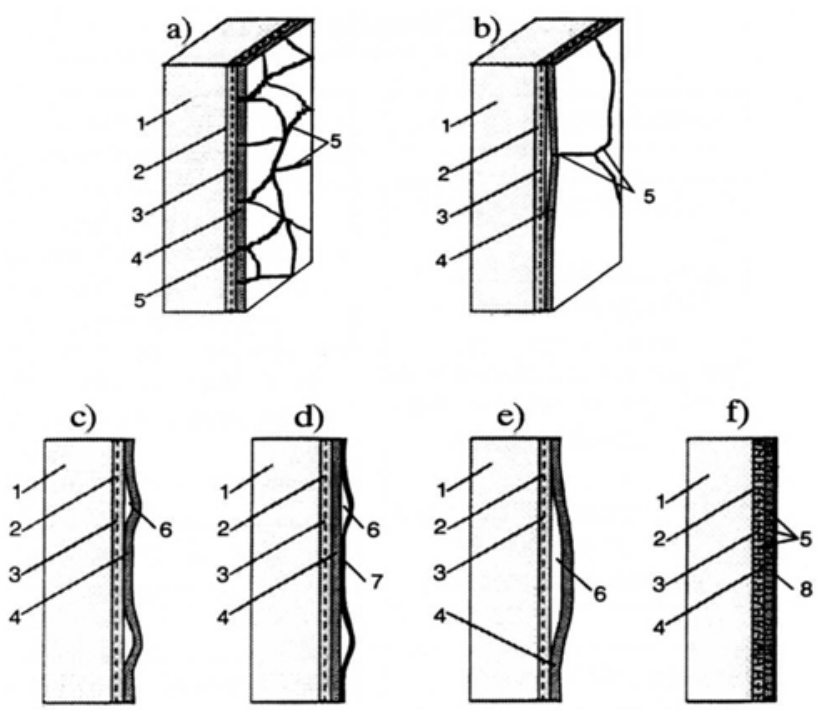

Fig 5. The schemes of deterioration for thin-layer plaster: 1 - thermal insulating material; 2- reinforcing render underlayer; 3 - reinforcing net; 4 - external finish plaster layer; 5 - cracks in external finish layer; 6 - blebs; 7 - external paint layer; 8 - external plaster layer which is forming at hardening

b) the cracks occur on external surface, they are growing, merging; the external layer is separating from its background by fragments similar to plates;

c) finish layer is separating from reinforcing one by little blebs;

d) little blebs occur when external paint layer is separating from its background;

e) external finish layer is separating from its background when big blebs are forming and growing, filling all the area of samples;

f) the deterioration signs cannot be noticed for a long time on external surface, but the layers deeper are quite destroyed.

The most important reasons of finish deterioration are these: ununiform thermal and ununiform moisture deformations of materials used, surplus vapour pressure, forming at intensive evaporation process when temperature of moist material is significantly increased, multiple freezing and thawing of accumulated water, insufficient adhesion of layers and, finally, the defect focuses left at manufacturing .

The different character of deterioration shows that the decisive reason of deterioration could be different in every case, but all of them are important during service life or testing, because of summing the destroying effects. 
Prof. G.Marčiukaitis has developed theoretical scheme of finish deterioration under consideration, based on calculations, where the effects of different deformations of layers, permeability of vapour, technological factors at manufacturing are evaluated [5].

The approvement of the theoretical presumption by experimental investigation has been our purpose. The physical-moisture properties of materials (vapour permeability, water absorption, moisture deformations, sorptional humidity) have been investigated separately and then the structural fragments made from materials under consideration have been tested in a climatic chamber under complex cycles simulating weather influence.

\subsection{The investigation of complex weather durability of} construction due to composition modifications and constructional conditions

The investigations of physical-moisture properties for separate components (materials) and dependencies of weather durability due to complex climate influence in a climatic chamber have been carried out with the purpose to check the expediency of the method selected and recognize the physical processes taking place in the finish layer.

The influence of plaster composition modification by PVA emulsion (variation of PVA -cement volume ratio) for weather durability of protective layer on expanded polystyrene insulation background due to complex climatic effects can be illustrated by the data in Fig 6.

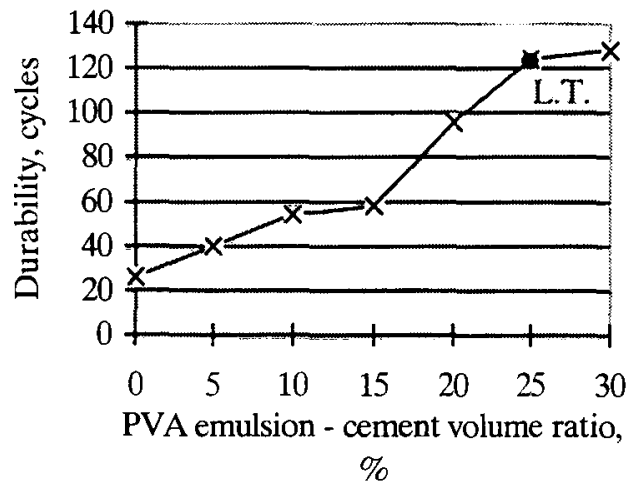

Fig 6. Dependence of weather durability on ratio of PVA emulsion - cement volume for plaster finish
According to the results of investigation, the weather durability of plaster is increased when the PVA emulsion - cement volume ratio is increased up to $25 \%$ (LT - turning point). It is established by the results of some test having been carried out at the ratio $30 \%$ and more, that the influence of this addition becomes negative and further investigations have been interrupted.

At the investigation, the dry mixtures for thin layer finish of external insulating systems made by foreign manufacturers have been modificated by the variation of water attenuation ratio, thus getting the materials with different physical properties. The water-dry mixture ratio, marked V/M in \% has been used to characterize mortar modifications in investigation. Complete insulating systems, as well as separate finish materials fixed on insulating material (expanded polystyrene foam board), have been tested with the purpose to establish the level of influence of separate finish components for the weather durability of insulating system. The investigation results are represented in Fig 7.
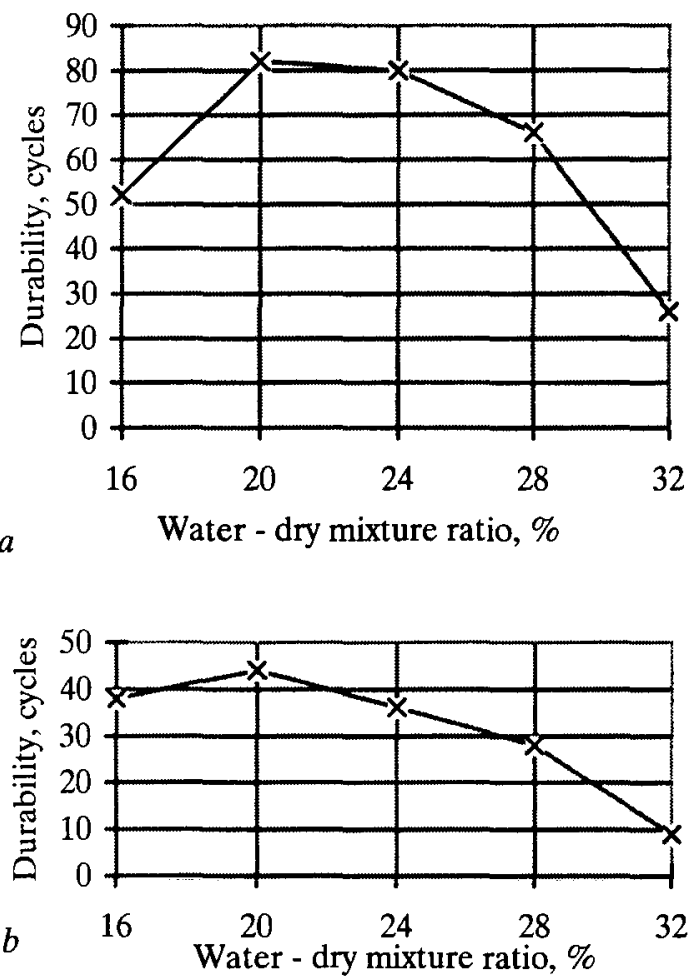

Fig 7. Weather durability due to complex climatic effects for finish layer in dependence on water - dry mixture ratio $a$ ) testing complete insulating system, $b$ ) testing finish layer on expanded polystyrene foam board only 
These data have testified that finish layer durability depends on background used for the finish. The results are twice better when the finish layer is installed on reinforcing background (complete insulating system, Fig 7a) in comparison with direct fixing of finish on expanded polystyrene foam board (dependence Fig 7b). Such outcome proves the necessity to test the weather durability due to complex climatic effects of complete insulating system instead of testing separate finish materials. The manufacturer has recommended the water-dry mixture ratio of $20 . .24 \%$ for tested finish material. And the results in Fig 7 show the same item.

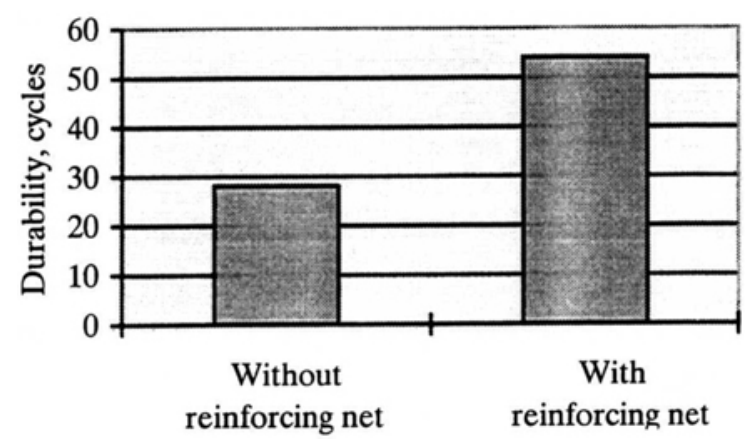

Fig 8. The effect of reinforcing net use for complex weather durability for finish plaster
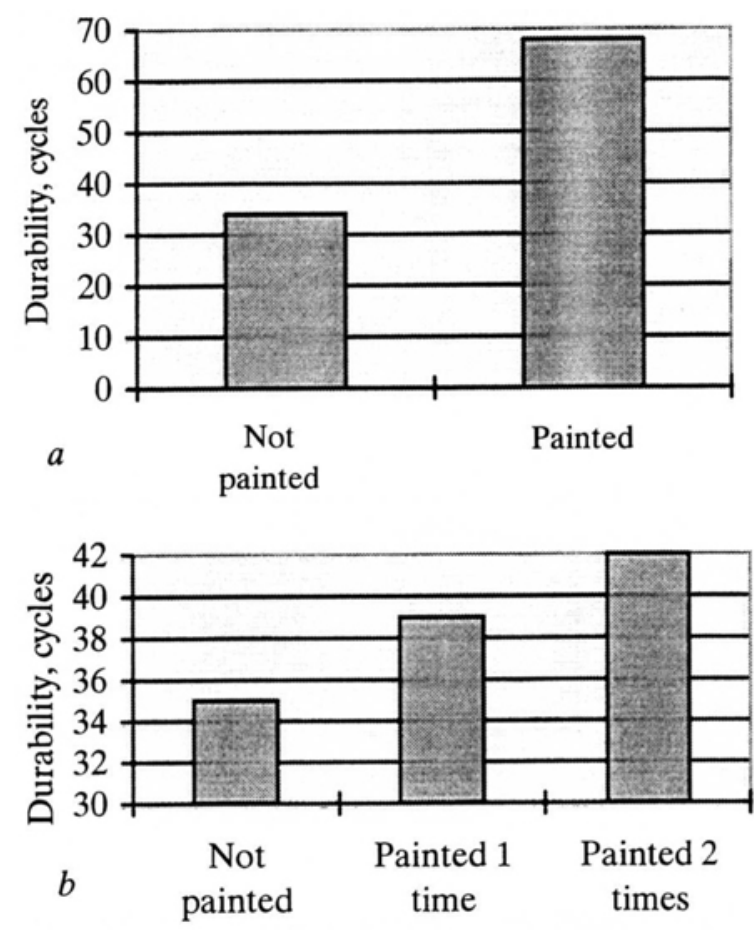

Fig 9. The effect of facade paint for complex weather durability of finish layer

a) finish plaster - Tex-Color Münchner Rauputz;

b) finish plaster - Heck Scheibenputz
The effect of reinforcing net installation and additional painting by water repulsive paint for weather durability has been investigated too. The received results are presented in Figs 8 - 9.

The investigation results presented in Figs $7-9$ would lead to the conclusion that the use of measures which increase the weather durability of finish system (as reinforcing net or additional painting by repulsive paint) under test according to selected method show better values, and vice versa, the use of measures which decrease the weather durability (test of incomplete finish system, attenuation level by water of dry mixture, too big or too low) show worse results respectively. It proves that the selected method is appreciated because of its expression of the qualitative property of finish system in weather durability cycles at testing in a climatic chamber, which simulate the freezing-thaw waves of winter season with temperature and humidity changes in outer layer.

\subsection{Interaction of materials physical properties in thin-layer protective-finish system}

It is widely known, that the outer finish layer of walls ought to be distinguished by low water absorption (impermeability) with the aim of protecting deeper layers from precipitation influence and good vapour permeability which pave the drying processes. At the same time, the mentioned properties determine the durability of the finish: at the decrease of water absorption the possibility of moisture amount to get into and participate in the deterioration of materials is decreased, and bigger vapour permeability ensure the more quick removing of moisture (drying). Properties under consideration are contradictory each other, thus optimal and critical combination of them, expressed in weather durability cycles, exists for every group of materials. Structural complex of external insulation system (insulating + reinforcing + finish layers) is formed at best combination of physical properties, which are often contradictory each other (at the increase of the value for one of physical properties effecting on weather durability, the other is decreased). Qualitative expression of such combination is represented in Fig 10. 


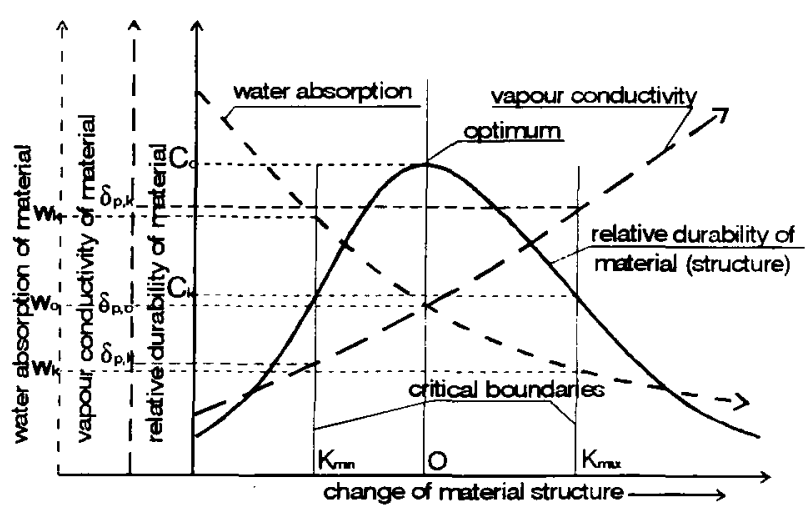

Fig 10. Principal scheme for optimization of material structure due to physical properties (vapour sorption, water absorption, durability)

The investigation in a climatic chamber has been carried out with purpose to determine the best combinations of interaction of parameters in construction under the modelled complex climatic effect (see Table 1)

Table 1. Method table for investigation of the influence of three physical parameters

\begin{tabular}{|c|c|c|c|c|c|}
\hline \multirow{2}{*}{$\begin{array}{c}\text { Plaster } \\
\text { mortar }\end{array}$} & \multicolumn{5}{|c|}{ Parameter } \\
\cline { 2 - 6 } & $C$ & $\delta_{p}$ & $u$ & $W$ & $w$ \\
\hline$p / c$ & + & + & - & - & - \\
\hline$p / c$ & + & - & + & - & - \\
\hline$p / c$ & + & - & - & + & - \\
\hline$p / c$ & + & - & - & - & + \\
\hline $\begin{array}{c}\text { Dry } \\
\text { mixture }\end{array}$ & $C$ & $\delta_{p}$ & $u$ & \multicolumn{2}{|c|}{$w$} \\
\hline$v / m$ & + & + & - & - \\
\hline$v / m$ & + & - & + & \multicolumn{2}{|c|}{-} \\
\hline$v / m$ & + & - & - & \multicolumn{2}{|c|}{+} \\
\hline
\end{tabular}

Where $p / c$ - mass ratio of PVA emulsion to cement, \%; $v / m$ - mass ratio of water to plaster dry mixture, $\%$; $C$ weathering cycles (complex influence) withstanded, cycles; $\delta_{p}$ - coefficient of vapour conductivity, $\mathrm{mg} /(\mathrm{m} \cdot \mathrm{h} \cdot \mathrm{Pa}) ; u$ water absorption by volume, $\% ; w$ - water sorption coefficient, $\mathrm{kg} /\left(\mathrm{m}^{2} \cdot \mathrm{h}^{0,5}\right) ; W$ - water surface sorption, $\mathrm{kg} / \mathrm{m}^{2}$.

To determine the best combination of interaction the chamber investigations were provided under modelled complex field condition cycles.

The summary of results received is presented in Fig 11 and 12.

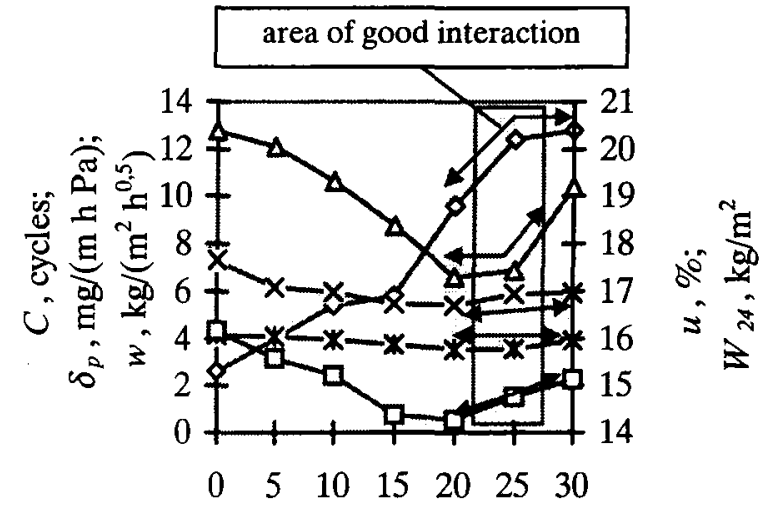

mass ratio of PVA emulsion to cement, \%

$-\infty-$ Weather durability (complex influence)

$-x-$ Vapour conductivity

- - Water absorption by ono surface

$\rightarrow-$ Water absorption by volume

$\checkmark-$ Water sorption coefficient (due to capillary moistening)

Fig 11. Dependence of physical parameters due to ratio of polymer - cement volume (polymeric modification of plaster) for plaster with best composition

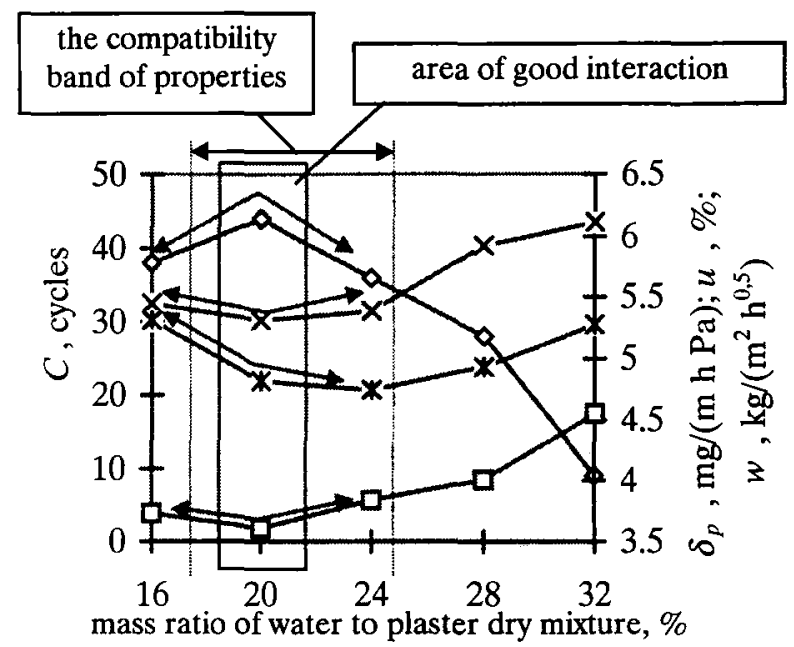

- -Weather durability (complex influence)
$-x-$ Vapour conductivity
$-\square-$ Water absorption by volume
$-x-$ Water sorption coefficient (due to capillary moistening)

Fig 12. Dependence of physical properties on thin-layer plaster due to the water-render dry mixture mass ratio 
Interaction of investigated physical properties can be described in the following mathematic expression:

$$
C=f\left(\delta_{p}, u, W, w\right)
$$

On the basis of the laboratory investigation analysis, the conclusion was made that at the approach of velocity of altering ratio for quantities of contradictory physical properties (ratios of first derivatives of altering curves) towards one, the weather durability of external additional insulating system is the largest :

$$
C_{o p t}=\frac{\varphi^{\prime}(w)}{\psi^{\prime}\left(\delta_{p}\right)} \rightarrow \frac{f^{\prime}(u)}{\varphi^{\prime}\left(W_{24}\right)} \rightarrow \lim 1
$$

where

$\varphi^{\prime}(W)$ - derivative of water absorption coefficient altering curve,

$\varphi^{\prime}\left(\delta_{p}\right)$ - derivative of vapour conductivity coefficient altering curve,

\section{Conclusions}

1. The main deterioration reasons of protective finish layers are:

- the different temperature and moisture related deformations of materials used;

- water vapour pressure arising mostly due to the intensive process of evaporation within an increase of the temperature in thin finish layer;

- local destructive centres which are formed at the junction of layers where the accumulation of moisture takes place during the moistening, drying and freezing of the construction;

- repeated freezing-thawing of accumulated water, especially in the primary local defect centres.

2. The weather durability of protective finish layer due to complex climatic influence is determined by the complex of physical properties, the most important of them are as follows: water vapour conductivity of the materials used in the discussed layer, water absorption, deformations due to temperature and moisture. Each above-mentioned property considered separately does not prove the same result as at the test under complex climatic effect. The positive results at testing of the materials under every separate effect can show less or even negative worth at the consideration of the complete structure.
3. The best interaction of the materials used for finish of external additional insulation of buildings is achieved at approach of rate in altering main physical properties ratios (quotient) of considered materials close one.

4. The weather durability of insulating systems due to the complex climatic effect can be increased by painting the external surface of thin plaster layer with water repulsive paints, the use of additions in finish layer mixtures decreasing the water permeability of layer, and the use of a reinforcing net.

\section{References}

1. E. Bagda. Hygrothermische Erfahrungen mit der Prüfwand nach UEAtc // Bauphysik, 10, 1988, S. 113-116.

2. Friedrich Heck, Bad Dürkheim. Einschalige Außendämmung von Außenwänden mit Polystyrol-Hartschaumplatten // Kunststoffe im Bau, 11, 1976, S. 22-31.

3. V. Stankevičius. Pastatų atitvarų drègmine būsena ir atsparumas šalčiui. Monografija. Kaunas: Technologija, 1997. $142 \mathrm{p}$.

4. A. Burlingis. Apdailos keraminiy plyty atsparumas klimato poveikiui. Technikos moksly daktaro disertacija. Kaunas, 1995. 157 p.

5. G. Marčiukaitis. Technologiniu faktoriu itaka sluoksniuotujų sienų išorinių sluoksnių supleišějimui // 5-osios tarptautinès konferencijos "Naujos statybinès medžiagos, konstrukcijos ir technologijos", ivykusios Vilniuje 1997 m. gegužès 21-24 d., straipsniai. IV t. Vilnius: Technika, 1997, p. 172-177.

İteikta 19980622

\section{PASTATŲ SIENŲ ŠILUMOS IZOLIACINIŲ SISTEMU SU PLONASLUOKSNIO TINKO APDAILA ILGAAMŽIŠKU- MAS}

\section{J. Ramanauskas, V. Stankevičius}

\section{S a n tra u k}

Papildomai apšiltintos sienos - santykinai nauja atitvarine konstrukcija Lietuvoje. Sienų šiltinimui ir išorès apdailai apsimoka naudoti tik kokybiškas, ilgaamžes ir kartu santykinai nebrangias medžiagas. Tam, kad statybose bütu naudojamos tik patikimos ilgaamžès medžiagos, reikia patikimos, moksliškai pagrịstos kokybès kontrolès ir ilgaamžiškumo prognozavimo metodikos.

Šiame darbe apibendrinta pastatų sieny išorinių sluoksniu atsparumo klimatui prognozavimo patirtis. Ištirtos apšiltinimo sistemose naudojamy apdailos medžiagy fizikinès savybès, konstrukcijoje vykstantys fizikiniai procesai. Pagrindinis demesys skiriamas ilgaamžiškumo bandymams klimatineje kameroje, kur konstrukcijos elementas (šilumos izoliacinè medžiaga +apdaila) veikiamas modeliuotais klimatiniu poveikių (lietinimas - šaldymas - šildymas) ciklais. Modeliuotais klimatinių poveikių ciklais bandant sienų ap- 
dailai skirtas medžiagas buvo gauti rezultatai, leidžiantys prognozuoti šių medžiagu ilgaamžiškumą Lietuvos klimato sąlygomis.

Pagrindinès apsauginiy apdailos sluoksniy irimo priežastys yra: nevienodos panaudotu medžiagu temperatūrinès-drègminès deformacijos, vandens garų slègis, susidarantis del intensyvaus garavimo procesy didejant drègnu plonasluoksnių medžiagu temperatūrai, sluoksnių sandūrose atsirandantys defektiniai irimo židiniai, kuriuose kaupiasi drègmè drékinimo, šaldymo ir džiūvimo metu, daugkartinis susikaupusio vandens užšaldymas ir atšildymas, ypač pirminių defektų židiniuose.

Plonasieniu apdailos sluoksnių, tiesioginiu būdu irrengtu ant apšiltinančio pagrindo, irimą pirmiausiai lemia visos plonasienès konstrukcijos išsisluoksniavimas ir išsigaubimas dèl klimato temperatūros ir drègmès kompieksinio poveikio. Ši procesą vèliau pagilina ir paspartina pačios medžiagos senejjimas ir irimas.

Apšiltinimo sistemų atsparumą kompleksiniams kimato poveikiams pagerina plonasienio tinko paviršiaus dažymas vandenị atstumiančiais dažais, vandens pralaidumą mažinančiu priedų naudojimas apdailos sluoksnių mišiniuose, armavimo tinklelio naudojimas.

Eksperimentais nustatytos priklausomybès tarp apdailai panaudoty medžiagu atsparumo kompleksiniams poveikiams klimatineje kameroje ir šiu medžiagu fizikiniudrégminių savybių. Geriausias šiltinamoje konstrukcijoje panaudoty medžiagų sąveikos derinys būna tuomet, jeigu tụ medžiagų svarbiausiu fizikiniu savybių santykių (dalmens) kitimo sparta artejja prie vieneto.

Siekiant tiksliau jivertinti pastatų sienu išorinio apšiltinimo sistemy̨ išorinio apdailos sluoksnio atsparumą klimato poveikiams, tikslinga papildomai modeliuoti kaitinimo-lietinimo ciklus, kurie įvertintų vasaros sezonui büdingus pavojingiausius klimato poveikių derinius.
Juozas RAMANAUSKAS. Doctor, research fellow. Institute of Architecture and Construction, Tunelio 60, Kaunas LT3035.

Research interests: weather durability of external wall, moisture in building.

Vytautas STANKEVIČIUS. Doctor Habil, Professor. Institute of Architecture and Construction, Tunelio 60, Kaunas LT-3035, Lithuania

Head of Building Thermal Physics Laboratory, Chairman of Scientific Council at Institute of Architecture and Construction, Chairman of Qualitative Commission for Architecture and Civil Engineering at Kaunas Technology University, Member of Lithuanian Fund of Science and Studies, Member of the Editorial Board of Journal "Civil Engineering", Member of ABOK (Russian Association of Heating, Ventilating and Air Conditioning Engineers), Expert member of Lithuanian Academy of Sciences, Coordinator for Lithuania at the CIB in the field of building thermal physics.

Author and co-author of more than 180 reports and papers, including 4 inventions, 1 monograph and 1 study guide, manager of working groups for 12 Building Codes.

Research interests: energy saving in buildings, weather durability of external wall layers, heat and mass transfer in building structures. 